\title{
Capital Inflows and Economic Growth in Selected COMESA Member Countries
}

\author{
Lucas Njoroge ${ }^{1}$
}

\begin{abstract}
This study examines the impact of capital inflows (FDI, ODA and Remittances) on economic growth in COMESA member countries. Applying System GMM estimation, the study finds a positive and significant relationship between capital inflows (except remittances) and GDP per capita growth, supporting the positive role capital inflows play in bridging the savings and investment gap, by providing finance for investment. However, remittances do not significantly influence GDP per capital growth. Remittances contribute positively to GDP per capita growth only when interacted with a variable for domestic financial depth.

Examining whether capital inflows adversely affect economic growth, the study finds that except for the remittances whose effect is not significant, capital inflows (FDI, ODA and total inflows) leads to an appreciation of the REER, that may be detrimental to growth. The parameter for remittances does not significantly effect REER, implying that remittances are in most cases used to smoothen households' consumptions during macroeconomic shocks and hence are counter-cyclical in nature. The study recommends, among others, financial sector reforms that will ensure increased depth of the domestic financial sector, capable of harnessing and providing efficient vehicles that can direct remittances for investment.
\end{abstract}

JEL classification numbers: F15, F21, F24, F35, F43, F45.

Keywords: Capital inflows, Economic Growth, COMESA.

${ }^{1}$ Senior Economist at the COMESA Monetary Institute.

Article Info: Received: October 6, 2021. Revised: October 28, 2021.

Published online: November 11, 2021. 


\section{Introduction}

Capital inflows in form of Foreign Direct investments (FDI), Remittances (REM), and Official Development Assistance (ODA) plays an important role in bridging the resource gap required for investment and economic growth especially in African countries. Most countries in the Common Market for Eastern and Southern Africa (COMESA) region are characterized by an overwhelming demand for investment required to accelerate economic growth and consequently reduce poverty, against limited and scarce resources for undertaking such investments, while tax revenues and savings remain low compared to the rest of the world. Consequently, external sources of finance such as FDI, Remittances, and ODA have gained prominence as alternative sources of finance for these countries. This study does not consider other categories of inflows such as portfolio inflows due to, among others, there levels are still very low and therefore the data is unavailable or extremely scanty over the study period, for most of these countries.

Capital inflows can also have adverse impact on growth through the appreciation of the exchange rate. The appreciation of the exchange rate can have a negative multiplier effect on the economy if it leads to a contraction of net exports and a rise in the demand for imports. Real appreciation of the exchange rate leads to loss of competitiveness widens the current account deficit as imports increases and exports decreases. Capital inflows have been associated with challenges in macroeconomic management and pressure in asset markets in a number of emerging economies and developing economies (Pradhan et al. 2011). At the extreme, excessive buildup of short-term capital inflows have been associated with vulnerability and financial crisis (Rodrik and Velasco, 1999).

Since most countries in the COMESA region have flexible exchange rate regimes, capital inflows leads to an appreciation of the real exchange rate due to increased supply of the foreign currency, that drives up the value of the domestic currency. This is through a rise in the nominal exchange rate rather than a rise in domestic prices. Capital inflows generates increased demand for both tradable and nontradable goods and both lead to a higher relative price of non-tradable goods, and to a real appreciation. Real appreciation of the exchange rate weakens the competitiveness of the country's exports and causes its export to decline. With time, resources (capital and labour) tend to shift to the production of domestic goods that are not traded internationally to meet the increase in domestic demand.

Studies on the relationship between capital inflows and economic growth remains inconclusive with some empirical studies supporting a positive relationship (Cho and Tien, 2014, and Omri and Kahouli, 2014) while others find a negative relationship (MacDonald, 2015 and Gourinchas and Jeanne, 2013). The negative relationship is generally explained by the macroeconomic challenges that emanate from sharp surges in capital inflows and tend to run counter to the objectives of domestic macroeconomic stabilization. Studies on the subject in the COMESA region remain scanty partly due to little importance given to other flows except ODA and partly due to little evidence concerning portfolio flows and other flows to 
the region until recently. Understanding how the various categories of capital inflows influence growth is especially important given that most economies in the COMESA region have fully or partially liberalized their capital account and operate flexible exchange rate regimes. The need for the region to deepen capital and financial market integration remains a priority as the region strive to harmonize monetary and financial systems. Assessing the influence of capital inflows on economic growth for the region provides valuable input for designing appropriate macroeconomic and financial sector policies that will hasten monetary and financial integration of the region in readiness to the eventual establishment of COMESA Monetary union.

\subsection{Trends in Capital inflows}

The region have been attracting sizeable amount of capital inflows over time. Foreign direct investment as a percentage of GDP (FDI) has been on an upward trend, increasing from regional average low of 1.1 percent of GDP in 1996 to a pick of 5 percent of GDP in 2007. This trend reversed sharply following substantial tightening of credit conditions in international markets on the onset of the global financial crisis. FDI flows recovered from a COMESA average low of 3.6 percent in 2009 to a peak of an average of 6.5 percent of GDP in 2012, because of various policy measures implemented in developed countries to deal with the global financial crisis including fiscal and monetary stimulus packages and measures to recapitalize financial institutions. The FDI inflows to the region have since been on a downward trend attributed to among others, change in investors' confidence, slow economic growth and competition from other destinations for investment (Figure $1)$.

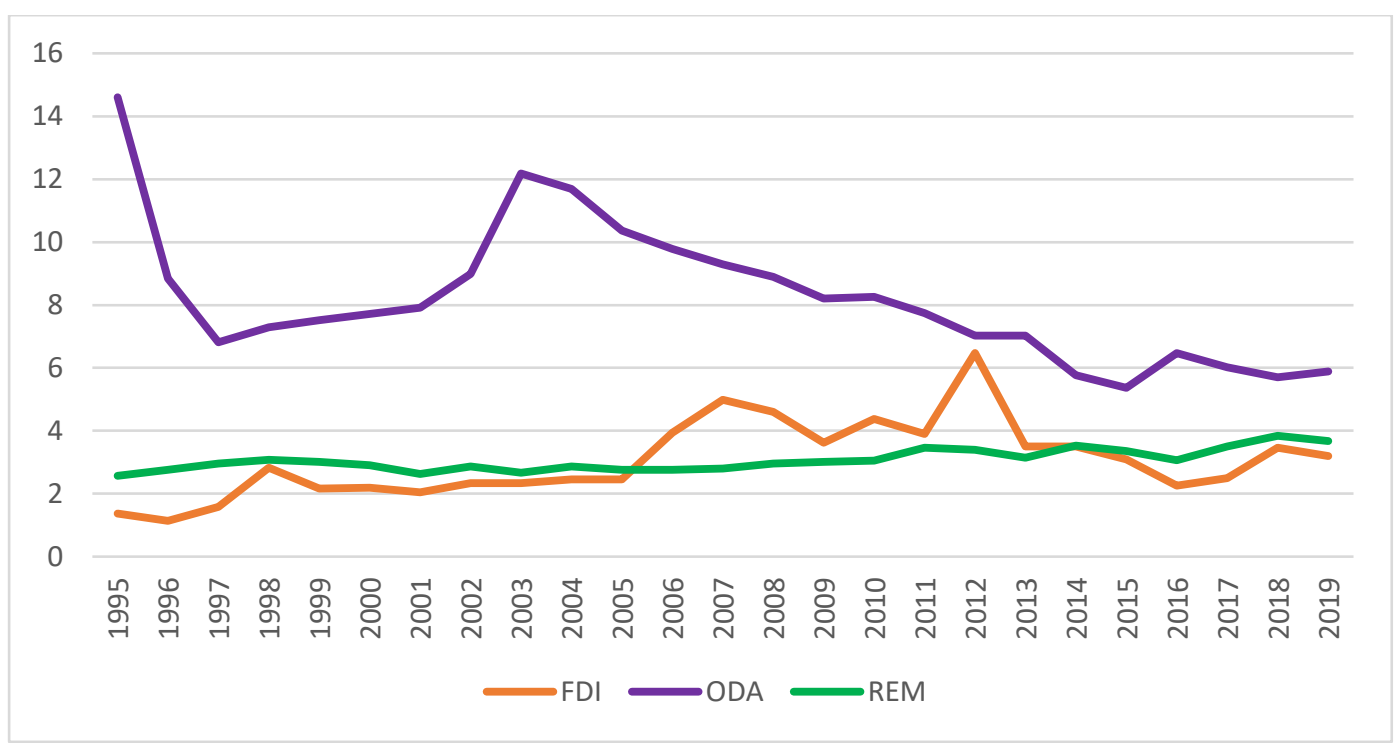

Figure 1: COMESA Average FDI, ODA and Remittances flow as a percentage of GDP 
COMESA average net ODA received as a percentage of GDP has been generally on the decline, from a COMESA average peak of 14 percent of GDP in 1995 to an average low of 5.4 percent of GDP in 2015. The decline can be attributed to among others, donor fatigue and change in development partners' approach to foreign aid that has tilted more towards project and programmes support. On the contrary, COMESA average personal remittances received as a percentage of GDP (REM) have remained resilient, steadily increasing from 2.6 percent of GDP in 1995 to a COMESA average of 3.8 percent of GDP in 2018, reflecting among other, the increasing importance of remittances inflows to the region (Figure 1).

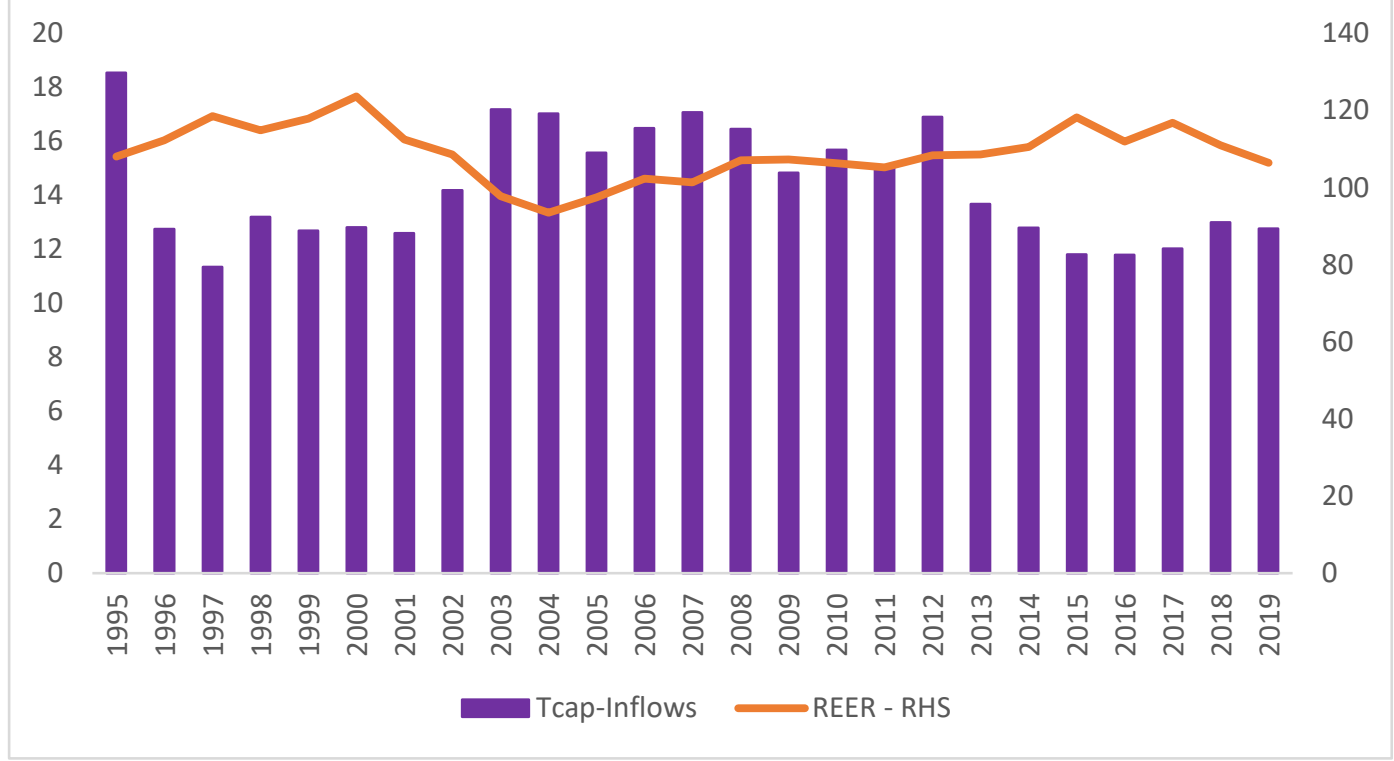

Figure 2: COMESA Total Capital Inflows and REER

Figure 2 indicates that total capital inflows as a percentage of GDP (sum of the average net FDI, net ODA and Remittances) to the region influences the REER with a lag. From a peak of 18.5 percent of GDP in 1995, capital inflows to the region seemed to influence the REER in subsequent years, appreciating the regional average REER index from 112.3 in 1995 to a peak of 123.7 in 2000. An increase in the REER index indicates an appreciation of the regional average REER index (reflecting that on average, COMESA regional currencies appreciated over the period) against a basket of currencies of trading partners. However, subsequent decline in average total capital outflow to the lowest point of 11.3 percent of GDP in 1997 may have influenced the REER depreciation over the period 2000 to 2004. Subsequent periods have generally indicated high and almost stable total capital inflows that have translated into stable but steadily appreciating regional currencies except after 2015 when the average REER index started to depreciate possibly due to declining average total capital inflows over the period 2012 to 2017. 


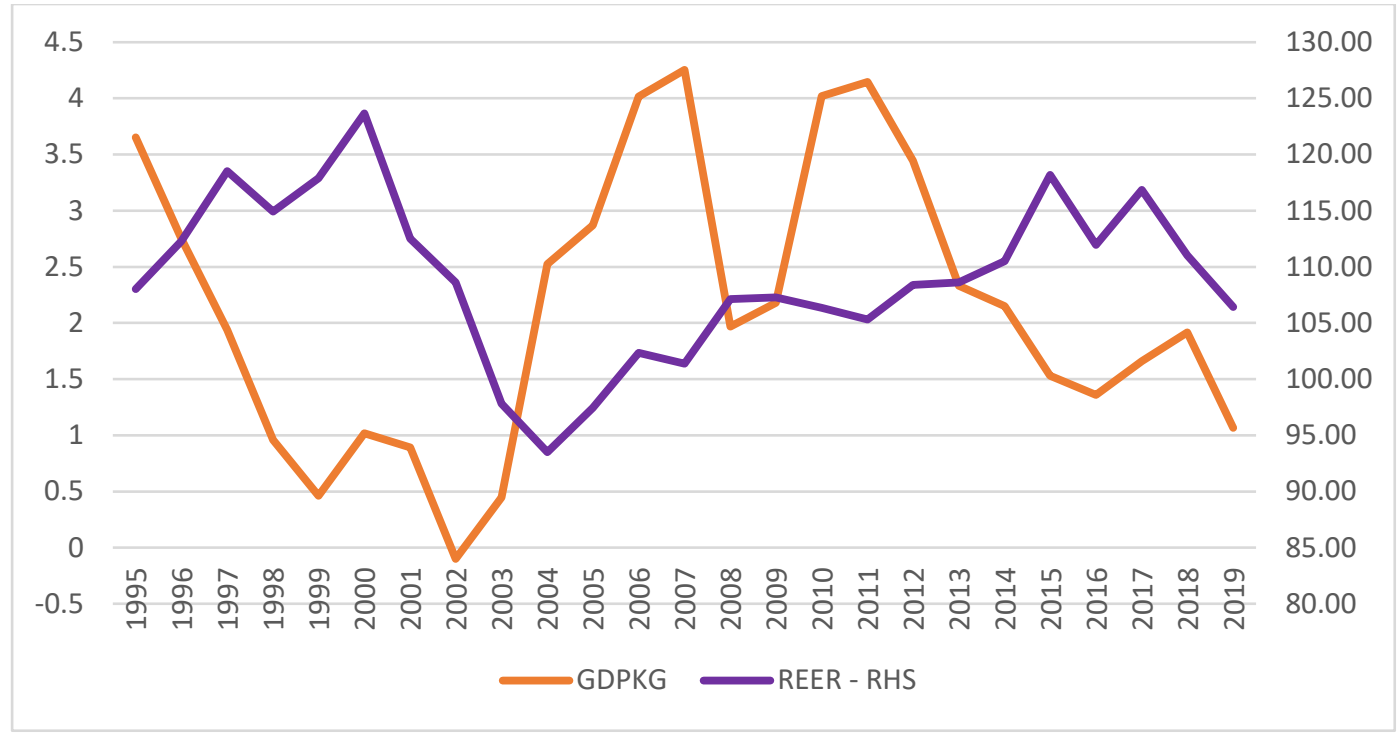

Figure 3: COMESA Average REER and GDP per capital growth

Figure 3 depicts almost an inverse relationship between GDP per capita growth and the REER. Starting with an appreciation of the REER of 14.5 percent between 1995 and 2000, the economy seems to have slowed down by 2.6 percent in GDP per capita terms over the same period. On the contrary, over the period 2002 to 2007, the REER depreciated by 7.2 percent while the GDP per capita grew by 4.4 percent. The impact of the global financial crisis indicate a 3.1 percent drop in the region's average GDP per capital growth from 4.3 percent in 2007 to 1.2 percent in 2008. However, with the region's economies relatively less integrated with the advanced economies, COMESA economies recovered relatively faster posting an average regional growth of GDP per capital of 4.1 percent by 2011. Thereafter, the region's economies GDP per capital growth has been on the decline. The region's average REER after the global financial crisis have been appreciating except after 2017 when it started to depreciate. The appreciation is indicative of the increasing financial flow to the region though not clear-cut and may require further empirical analysis. 


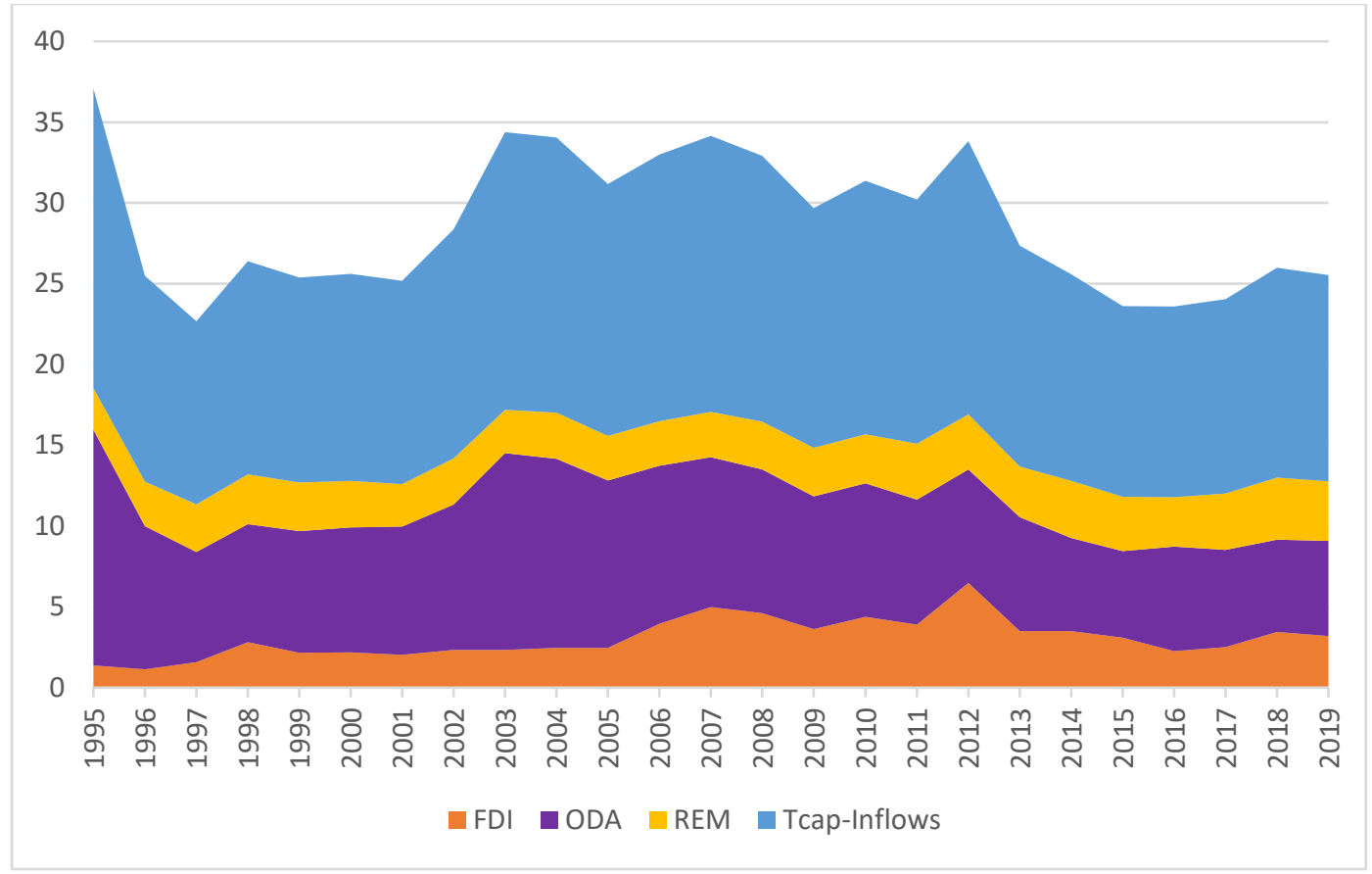

Figure 4: Categories of Capital Inflows (FDI, ODA, Remittances ad Total Inflows as a percentage of GDP

Figure (4) shows that ODA inflows have been consistently larger than the other inflows for the region, probably depicting the large number of countries in COMESA region that rely heavily on overseas development assistance. However, FDI inflows have started to gain traction and are becoming an important source of finance as preference shifts toward more stable sources that are less prone to volatility and capital reversal, which ordinarily requires precautionary foreign exchange reserve holding to circumvent capital flight. The workers remittances amounts seems to be stabilizing to an average of about 3 percent of GDP over the entire period. With total inflows averaging about 14.3 percent of GDP for the entire period, this study examines whether these relatively substantial inflows have affected (positively or negatively) economic growth in the COMESA region.

\section{Literature Review}

The theoretical basis of the influence of capital inflows on economic growth can be traced to the benefits of capital market integration, which allows separation of savings and investment decisions. Countries overcome savings and investment constraints by borrowing abroad to finance domestic investments, allowing capital scarce countries to increase their growth rates by investing more without reducing consumption and welfare. International financial integration allows risk sharing between countries and increases economic growth (Blanchard and Fischer, 1989 and Obstfeld, 1994). Deléchat et al, C (2009) also finds considerable gains from 
financial integration even when the world is not frictionless.

However, there is also a theoretical basis for financial inflows to cause economic decline. In the presence of moral hazards, Mckinnon and Pill (1997) shows that foreign financing may stimulate domestic banks to engage in excessive lending. This may result in sector wide higher nonperforming loans and excessive defaults that if wide scale may require an expensive bailout, financial sector disruption and economic decline. Similarly, Rodrik and Velasco (1999) show that excessive lending may lead to liquidity challenges and bank runs, costly asset liquidations and economic decline.

On the empirical front, a number of studies on economic growth have included one or more proxies for capital inflows. The results of these empirical studies remain mixed in terms of the significance of various capital inflow measures. Some studies also do not distinguish the different types of capital inflows while most treat each of the capital inflows separately in the analysis of the contribution of capital inflows to economic growth. In terms of the influence of capital inflows on economic growth, some studies find that capital inflows positively influences growth while others find that capital inflows negatively influences economic growth. We examine a brief overview of how each of the categories of capital inflows (FDI, ODA and remittances) influences economic growth.

On positive contribution of capital inflows to economic growth, empirical literature show that FDI influences growth directly through increased output and indirectly through transfer of technology, managerial know-how and other intangible assets to domestic firms that also increases the national output (Kinda, 2009). FDI affects economic growth directly through establishing presence in an economy and contributing to the production of goods and services, and indirectly when local firms increasing exports through imitating the multinational firms or by using the transport, communication and financial services infrastructures developed to support the activities of the FDI ventures. Vertical FDI seeking cost efficiency, enables a subsidiary to maximize on cheap labour and raw materials in the host country, increasing re-export and production. In addition, FDI may influence competitiveness of firms in host countries or through technology spillover, enhance production and growth. The role of FDI on economic growth depends on the forms of FDI, with different forms of FDI's having different impact on economic growth. FDI may negatively affect growth especially in low-income resource rich African countries if natural resource exports deters or crowd-out the domestic manufacturing sector. The opposite effect happens if FDI goes to manufacturing sector, thereby allowing spillover of foreign knowhow to domestic firms, which may include technical or vocational training, and technologies that are more efficient. Driffield and Jones, 2013 finds that FDI contributes more to economic growth than domestic investment especially where FDI entails technology transfer, with the effect more pronounced in countries with more developed domestic financial markets and broader institutional framework. De Mello (1999) finds that FDI positively affects economic growth through capital accumulation or through knowledge transfer by augmenting existing stock of knowledge. Almfraji et.al 
(2014) shows that FDI play an important role in development and economic growth. On positive contribution of ODA to economic growth, Rajan and Subramanian (2005) do not find clear evidence to support a positive and significant impact of ODA on economic growth. On the contrary, Adedokun (2017) finds a positive and robust impact of ODA on provision of health care, primary education and in alleviating poverty. The ambiguity of the contribution of foreign aid to growth has shifted the empirical analysis to why aid may be ineffective in influencing economic growth. The debate is tilted towards, first, whether countries that pursue sound and quality economic policies show better aid effectiveness. Burnside and Dollar (2000) concludes that aid attracts private investment in a good policy environment but poor policy environment discourages private investment, making aid ineffective. However, Lensink and White (2000) among others, challenges this conclusion and argue that aid can affect growth through other channels, and that there is ambiguity in what constitute good policies. Second, whether effectiveness of aid depends on quantity of aid, which in turn systematically affects the quality of policies. In this case, foreign aid is seen as an inducement for policy reforms. Alesiena and Dollar (2000) show that the quantity of aid does not systematically influence the quality of policies even when aid has conditionalities.

On the contrary, Collier and Dollar, (2002) show that for a number of African countries, relatively high levels of foreign aid and initiatives to strengthen policies coincided with high and sustainable real GDP per capita growth over a decade. Other studies find that effectiveness of foreign aid depends on the quality of institutions and aid fungibility - diverting foreign aid to other unintended projects, which tends to reduce aid effectiveness. That is, foreign aid significantly and positively affects economic growth, as long as the resources are utilized for the intended purpose (Quattara, 2006). The World Bank (1998) show that for countries with poor policies and weak institutions, aid tend to be fungible. Some studies analyze whether aid effectiveness is affected when foreign aid is tied. Alesiena and Dollar (2000) show that tied aid reduced the value of foreign aid by between 25 40 percent, since it forces recipient countries to purchase uncompetitively priced imports, making aid ineffective.

Similarly, Giuliano and Ruiz-Arranz (2009) finds that remittances positively and significantly influences economic growth, depending on a country's economic policies and quality of institutions. However, the extent of brain drain can dampen the positive impact of remittances on economic growth. The decline in productive capacity due to loss of skilled labour associated with brain drain is however difficult to assess since it depends on both the opportunity cost of migrants working abroad and the home country's unemployment rate, of which both are difficult to quantify or the data is scanty.

A number of studies use more than one category of capital inflows in the analysis of the contribution of capital inflows to growth (Driffield and Jones 2013, and Zardoub and El Abed 2019). Javaid (2017) study on Pakistan finds that remittances do not contribute to economic growth but FDI and ODA significantly contributed to economic growth. The insignificant outcome was largely attributed to usage 
where remittances were used to smoothen consumptions unlike FDI and ODA that went into investment. Zardoub and El Abed (2019) models the short and long term effects of capital flows on economic growth in developing countries using a combined autoregressive distributed lag panel approach, and finds an ambiguous effects. Murinde (2012) shows that the impact of capital inflows on economic growth depends on the sample used, model specification and treatment of inherent endogeneity bias.

Javaid (2017) study on Pakistan finds that FDI and ODA had a significant and positive impact on economic growth, while remittances did not influence economic growth. The study argues that the reason why remittances did influence economic growth were, first, remittances were used for consumption and second, remittances led to exchange rate appreciation that made Pakistan's exports uncompetitive. In a similar study, Aizenman et al. (2011) finds that FDI positively affects growth but portfolio inflows and equity investments have no effect on economic growth.

Coon and Neumann (2015) study of 118 developing countries from 1980-2010 finds that remittances and FDI are complementary, both filling the resource gap for investment, thereby positively influencing economic growth in the recipient country. Similarly, Lensink and Morrissey (2000) finds that migrant remittances and foreign aid are complementary. They argue that remittances directed to investment in the home country tends to stimulate infrastructure development and growth of quality institutions, that ultimately trigger foreign aid inflows and economic growth. However, Minasyan and Nunnenkamp (2016) provide a contrary view that foreign aid does not lead to any improvement in infrastructure, institutions or economic growth in recipient country, which in turn discourage remittances and dampen economic growth prospects.

Some studies for Africa or Sub-Saharan Africa (SSA) on capital inflows and economic growth find a significant positive relationship. Alley (2015) finds a positive and significant relationship between FDI per capita and GDP growth per capital and a negative relationship between portfolio investment per capita and bank lending per capita and GDP growth per capita. Delechat et al. (2009) using OLS over a period 2000-7, finds a significant positive relationship between capital inflows and real GDP growth. The main shortcoming of the study was the short span of data and the use of OLS that does not give consistent parameter estimates for panel data. Mougani (2012) using OLS estimation finds a significant positive effect of capital inflows and GDP growth but the results did not hold when using GMM estimation.

The negative impact of capital inflows on economic growth in the empirical literature is captured through the impact of such inflows on the real effective exchange rate. The negative consequences arise from loss of competitiveness caused by a real effective exchange rate appreciation associated with capital inflows. Capital inflows generate increased demand for both tradable goods and non-tradable goods and lead both to a higher relative price of non-tradable goods and to real appreciation. This is necessary so that domestic resources will be diverted to production of non-tradable goods to meet the increased demand (Edwards, 1998). 
With most COMESA member countries having flexible exchange rates, a real appreciation emanates from nominal appreciation, which in turn undermines competitiveness, widens the current account deficit as imports becomes cheaper and exports expensive, and increases vulnerability to a financial crisis (Calvo et. al 1993). Sustained and significant appreciation can lead to sudden stop of capital inflows, causing an abrupt adjustment of the current account, discouraging investment and could cause major problems for macroeconomic management of the economy (Lartey, 2008).

In general, the impact of foreign aid on REER is mixed. Foreign aid inflows causes real exchange rate appreciation only if it enhances productivity in the tradable sector but leads to exchange rate depreciation if directed to improve productivity in the non-tradable sector (Cerra, et.al. 2008). Similarly, empirical studies on the impact of FDI on exchange rate is not clear. Lartey (2007) and Saborowiski (2009) show that FDI inflows leads to real appreciation while Athukorala and Rajatirana (2003) show that FDI inflows are associated with a depreciation. In addition, there is no consensus on the impact of remittances inflow on real REER. Remittances can be countercyclical, that is, acting as a buffer to smoothen consumption especially during economic downturn. In this case, remittances provide the much-needed cushion by compensating for foreign exchange losses due to macroeconomic shocks and therefore tend not to have much effect on the REER (Bourdet and Falck, 2006). However, remittances can be procyclical when they are directed towards investment, contributing to further macroeconomic overheating and appreciation of the REER (Saadi-Sedik and Petri, 2006). Procyclical remittances spent on real estate increases input prices, giving rise to construction booms, while if remittances are spent on traded goods such as imported durables, their effects on REER is weaker (Chami et. al., 2008)

The foregoing empirical literature indicate that there is still no consensus on the relationship between capital inflows and economic growth. The literature suggest that the results depend on among others, the choice of time span/period with shorter time periods regarded more restrictive for robust results, choice of estimation technique with consensus inclined towards panel data estimation, and the choice of countries and variables to include. Most empirical studies remain biased towards emerging or developed countries, with no study on the subject so far for COMESA region. COMESA region aspiration of having a monetary union requires a deeper understanding of the effects of capital inflows and economic growth in order to inform policy discourse on the implication of financial integration within and with the rest of the world. This study addresses some of these gaps by analyzing the effect of capital inflows on economic growth for selected countries in the COMESA region. 


\section{Methodology}

\subsection{The Growth Model}

Empirical studies on the contribution of capital inflows to economic growth traces its theoretical underpinning from the neo-classical framework with the basic model articulated by Solow (1956). The most basic Solow's growth model shows that:

$Y_{t}=F\left(K_{t} ; L_{t}\right)$

$\mathrm{Y}_{\mathrm{t}}$ is total production at time $\mathrm{t}$, which is a function of the stock of physical capital $(\mathrm{K})$ at time $\mathrm{t}$, and the Labour force at time $\mathrm{t}$.

The evolution of the economy in per capita terms is determined by

$\dot{k}=s f(k)-n k$

Where $\dot{k}$ is the derivative of capital per capita $(\mathrm{k}), \mathrm{s}$ is the savings rate and $\mathrm{n}$ is the population's growth rate and $\mathrm{f}(\mathrm{k})$ is the production per capita.

Empirical studies have been extended model equation 1 and 2, to show that output depends on capital, labour, total factor productivity as a measure of technological progress, and a host of other control variables (Kose et al. 2010; Calderon and Nguyen 2015).

Following such studies, this study incorporate capital inflows variables through the capital stock because such inflows are required to augment domestic resources in a capital scarce economy. That is, capital inflows compliment savings in capital scarce economies and therefore reduce the cost of capital and increase domestic investments. Accommodating the panel nature of the data for cross-country analysis, this study estimates the following general panel model:

$y_{i t}=\beta_{01}+\beta_{1 i} y_{i t-1}+\beta_{2 i} K_{i t}+\alpha_{j i} \sum_{j=1}^{n} W_{j, i t}+\mu_{i}+\varepsilon_{i t}$

Where $y_{i t}$ is the real GDP per capital growth in country $i$ at time $t, K_{i t}$ is a measure of capital inflows and $\mathrm{W}_{\mathrm{it}}$ is a set of control variables that determines real GDP per capita growth. In panel data context, $\mu_{\mathrm{i}}$ represents country effects, capturing unobserved characteristics and $\varepsilon_{\text {it }}$ is an error term.

Measures of capital inflows used in this study are Foreign Direct investments (FDI), Remittances (Rem) and Official Development Assistance (ODA), expressed as a percentage of GDP. Data on other capital inflows such as portfolio flows is lacking for a majority of COMESA member countries due to, among others, the low level of development of the domestic financial markets to facilitate such flows. 
Hence, equation 3 becomes:

$y_{i t}=\beta_{01}+\beta_{1 i} y_{i t-1}+\beta_{21} F D I_{1 t}+\beta_{22} O D A_{2 t}+\beta_{23} \operatorname{Rem}_{3 t}+$ $\alpha_{j i} \sum_{j=1}^{n} W_{j, i t}+\varphi_{i}+\omega_{i t}$

Controlling for most of the usual determinants of economic growth, real GDP per capital growth is explained by investment rate (captured by gross fixed capital formation as a percentage of GDP- GFKF) as a ratio of GDP to capture the role of investment in the growth process. Inflation (INF) measured in annual percentage change of the GDP deflator to capture macroeconomic stability and government final consumption expenditure (GCON) as a ratio of GDP used as a fiscal indicator. Other control variables include: the degree of openness (OPEN) as a ratio of GDP measured as the sum of exports and imports of goods and services; Private sector credit as a ratio of GDP (PSC) or Broad money as a ratio of GDP (BM) to measure the role of domestic financial depth in economic growth; Population Growth (POP) measured in annual percentage change to capture the role of human capital in economic growth (data on other better proxies for human capital development such as secondary school enrolment is not available for our sample of countries over the entire study period); and, Real Effective Exchange Rate (REER). Variables expressed as a ratio of GDP controls for the heterogeneity of economic size across the COMESA region.

\subsection{The REER Model}

To capture the likely detrimental effects of financial inflows on economic growth, we estimate the effect of each category of net capital inflows on the real effective exchange rate (REER). Following similar studies on REER (Saborowski, 2009 and Zardoub and El Abed Riadh, 2019), we model the key macroeconomic determinants of REER as follows:

$R E E R_{i t}=\propto_{01}+\propto_{1 i} R E E R_{i t-1}+\propto_{21} F D I_{1 t}+\propto_{22} O D A_{2 t}+\propto_{23}$ Rem $_{3 t}+$
$\alpha_{j i} \sum_{j=1}^{n} Z_{j, i t}+\mu_{i}+\varepsilon_{i t}$

Where REER ${ }_{\mathrm{it}}$ is the Real Effective Exchange Rate for country $i$ at time $t$, and $Z_{\mathrm{j}, \mathrm{it}}$ are the key determinants of the real effective exchange rate for countries in the COMESA region. An increase in the REER denotes an appreciation and hence a loss of competitiveness and vise-vasa for a decline in REER.

Beside the capital inflows variables (FDI, ODA, REM and Tinflows), the main control variables for the REER model include the following: trade openness (OPEN); Terms of Trade (TOT); Balassa Samuelson Index (BSI), computed as a country's GDP per capita relative to the weighted average GDP per capita of COMESA's major trading partners and aims to reflect the impact of the increasing 
price of non-tradable goods over the development process within a sample for which per capita GDP levels are quite heterogeneous; and, Government final consumption expenditure (GCON) as a ratio of GDP as a government fiscal indicator.

We estimate equations (4) and (5) using System Generalized Method of Moments (sys-GMM) estimator. We choose system GMM for two main reasons. First, system GMM estimator ensures that the estimates are consistent even when a lagged dependent variable is one of the regressors. Second, system GMM estimation addresses the problem of endogeneity of the explanatory variables due to measurement errors, reverse causality, or omission of relevant variables (Arellano and Bond, 1991; Arellano and Bover, 1995; and, Blundell and Bond, 1998).

\subsection{Data}

Most empirical studies on growth are based on five-year average observations, which requires availability of long time spans of over thirty years for all the variables. Data especially for capital inflows variables for COMESA member countries is scanty and becomes relatively comprehensive from 2005 while the most recent period with data is 2019, restricting our study period to 2005-2019 for 17 COMESA member countries out of a total membership of 21 countries. The other four countries lack continues data over the study period. System GMM is especially useful with "small T, large N" panels, meaning few time periods and more countries as is the case in this study. System GMM is also useful to address the case where there are independent variables that are not strictly exogenous, meaning correlated with past and possibly current realizations of the error, especially for the case where a lagged dependent variable is one of the regressors. System GMM also addresses the challenges posed by country fixed effects, heteroskedasticity and autocorrelation in the data.

Given the relatively short span, this study uses annual data instead of the five-year average data that assumes that business cycle disturbances are averaged out in each of the five-year. Although this is a very important assumption for advanced countries, where business cycles have been established to last an average of about 5 years, the same cannot be inferred for COMESA countries, where business cycles spans have not been clearly established. Most countries in the region only experience output fluctuations and not business cycles (Cho and Tien, 2014). Therefore, estimation based on annual data may not be implausible and could be more relevant for COMESA member countries. In any case, cyclical components specific to each country that are not captured by the regressors will be contained in the residuals. This may mean that the residuals are correlated with the regressors, making the estimates inconsistent. By estimating the models with system GMM helps address this inconsistency in estimates. Data list, description and sources are provided in Table 1A in the Appendix. 


\section{Results}

The system GMM estimator involves combining the equation in levels and equation in first differences into a system and estimating the system using lagged differences and lagged levels of the explanatory variables as instruments. This reduces endogeinity bias since the lagged values used as instruments for capital inflows are not affected by the contemporaneous levels of economic growth (Arellano and Bond, 1991; Arellano and Bover, 1995; and, Blundell and Bond, 1998).

We conduct system GMM by estimating each equation in first difference to remove country fixed effects. Then, the equation in levels is combined with the first difference equation in a system and estimated with lagged differences (in the levels equation) and lagged levels of the explanatory variables (in the first difference equation) used as instruments.

\subsection{Estimation of the Growth Model}

We estimate the growth model (equation 4) twice. First using the Private Sector Credit (PSC) as a percentage of GDP in Table 1 and second, using Broad Money as a percentage of GDP (BM) in Table 2. The variables PSC and BM are proxies for domestic financial sector depth. The use of these two variables capturing domestic financial depth is especially important in this study because they provide some understanding of the nexus between capital inflows and the regions quest for deeper capital and financial market integration.

Table (1) present the results for the first set of estimation that uses domestic credit to private sector as a percentage of GDP (PSC) to measure the role of domestic financial depth in economic growth. In equation (1), we use foreign direct investment as a percentage of GDP as our capital inflow variable while in equation (2), (3) and (4) we use Net ODA as a percentage of GDP, remittances as a percentage of GDP and total inflows as a percentage of GDP as the capital inflow variables, respectively. 
Table 1: Dependent Variable: GDP per capita growth (annual \%) - GDPKG

\begin{tabular}{|c|c|c|c|c|c|}
\hline System GMM Estimation & (1) & (2) & (3) & (4) & (5) \\
\hline $\begin{array}{l}\text { Lag GDP per capita growth } \\
\text { (annual \%)-GDPKG(-1) }\end{array}$ & $\begin{array}{l}0.889 * * * \\
(0.084)\end{array}$ & $\begin{array}{l}0.915^{* * *} * \\
(0.081)\end{array}$ & $\begin{array}{l}0.915 * * * \\
(0.081)\end{array}$ & $\begin{array}{c}0.895 * * * \\
(0.052)\end{array}$ & $\begin{array}{c}0.909 * * * \\
(0.026)\end{array}$ \\
\hline $\begin{array}{l}\text { Foreign direct investment, net } \\
\text { inflows ( } \% \text { of GDP)-FDI }\end{array}$ & $\begin{array}{l}0.179^{*} \\
(0.094)\end{array}$ & & & & \\
\hline $\begin{array}{c}\text { Net ODA received } \\
(\% \text { of GDP })-O D A\end{array}$ & & $\begin{array}{l}0.29 * * * \\
(0.0247)\end{array}$ & & & \\
\hline $\begin{array}{c}\text { Personal remittances, received } \\
(\% \text { of GDP)-REM }\end{array}$ & & & $\begin{array}{c}0.183 \\
(0.125)\end{array}$ & & \\
\hline $\begin{array}{l}\text { Total inflows as a percentage of } \\
\text { GDP-Tinflows }\end{array}$ & & & & $\begin{array}{c}0.26 * * * \\
(0.043)\end{array}$ & \\
\hline REM*PSC & & & & & $\begin{array}{c}0.074 * * * \\
(0.027)\end{array}$ \\
\hline $\begin{array}{c}\text { Domestic credit to private } \\
\text { sector }(\% \text { of GDP)-PSC }\end{array}$ & $\begin{array}{l}0.23 * * * \\
(0.057)\end{array}$ & $\begin{array}{c}0.277 * * * \\
(0.048)\end{array}$ & $\begin{array}{c}0.278 * * * \\
(0.146)\end{array}$ & $\begin{array}{c}0.268 * * * \\
(0.036)\end{array}$ & $\begin{array}{c}0.254 * * * \\
(0.083)\end{array}$ \\
\hline $\begin{array}{l}\text { Gross Fixed Capital Formation } \\
\text { (\% of GDP)-GFKF }\end{array}$ & $\begin{array}{l}0.278 * * * \\
(0.016)\end{array}$ & $\begin{array}{l}0.253 * * * \\
(0.041)\end{array}$ & $\begin{array}{l}0.265 * * * \\
(0.039)\end{array}$ & $\begin{array}{c}0.276^{* * *} \\
(0.092)\end{array}$ & $\begin{array}{l}0.183 * * * \\
(0.045)\end{array}$ \\
\hline REER & $\begin{array}{l}-0.005 * \\
(0.003)\end{array}$ & $\begin{array}{c}-0.002^{* *} \\
(0.004)\end{array}$ & $\begin{array}{c}-0.002 * * * \\
(0.006)\end{array}$ & $\begin{array}{c}-0.009 * * \\
(0.002)\end{array}$ & $\begin{array}{c}-0.092 * * * \\
(0.018)\end{array}$ \\
\hline $\begin{array}{c}\text { Population Growth } \\
\text { (annual \% change)-POP }\end{array}$ & $\begin{array}{l}0.98 * * * \\
(0.338)\end{array}$ & $\begin{array}{l}0.90 * * * \\
(0.293)\end{array}$ & $\begin{array}{l}0.968 * * * \\
(0.31)\end{array}$ & $\begin{array}{l}0.914 * * * \\
(0.297)\end{array}$ & $\begin{array}{c}0.932 * * * \\
(0.016)\end{array}$ \\
\hline $\begin{array}{l}\text { Inflation, GDP deflator } \\
\text { (annual \%)-INF }\end{array}$ & $\begin{array}{l}-0.007 * * \\
(0.004)\end{array}$ & $\begin{array}{l}-0.002 * * * \\
(0.0004)\end{array}$ & $\begin{array}{c}-0.002 * * \\
(0.001)\end{array}$ & $\begin{array}{c}-0.002 * * \\
(0.001)\end{array}$ & $\begin{array}{r}-0.0008 * * * \\
(0.00003)\end{array}$ \\
\hline $\begin{array}{c}\text { General government final } \\
\text { consumption expenditure } \\
(\% \text { of GDP)-GCON }\end{array}$ & $\begin{array}{l}0.018 * * * \\
(0.007)\end{array}$ & $\begin{array}{l}0.018 * * * \\
(0.007)\end{array}$ & $\begin{array}{c}0.013 \\
(0.009)\end{array}$ & $\begin{array}{l}0.081 * * * \\
(0.026)\end{array}$ & $\begin{array}{c}0.088 * \\
(0.05)\end{array}$ \\
\hline OPEN \%GDP & $\begin{array}{l}0.053 * * \\
(0.027)\end{array}$ & $\begin{array}{c}0.059 \\
(0.075)\end{array}$ & $\begin{array}{l}0.002 * \\
(0.001)\end{array}$ & $\begin{array}{l}0.06^{* *} \\
(0.029)\end{array}$ & $\begin{array}{l}0.051 * * * \\
(0.012)\end{array}$ \\
\hline
\end{tabular}

As shown in Table 1, FDI, ODA and total capital inflows all have positive and significant coefficients, implying that the three categories of capital inflows positively influences per capita GDP growth in the region. However, the parameter associated with remittances is not statistically different from zero suggesting that remittances do not seem to influence economic growth for the selected COMESA countries. This may imply that remittances are used to smoothen consumption and not for investment purposes and therefore have no impact on economic growth. Another reason for insignificant impact of remittances on economic growth may be the potential disincentives effects of remittances on labour market participation (Giuliano and Ruiz-Arranz, 2009). 
On the other determinants of economic growth, the lagged GDP per capita growth has a positive and significant parameter across the five equations, meaning that a country that performed better in a previous period is likely to continue performing well in the current period, suggesting growth divergence among the countries in the region. The private sector credit (PSC) parameter is significant and positively related to growth in COMESA. This is contrary to the findings by Easterly et al. (2004) that financial sector depth increases the likelihood of a downturn and hence negatively affecting growth. The result suggests that domestic private sector credit growth in the region reflects increasing financial inclusion and more access to credit for a region characterized mostly by credit constrain. For robustness check, we use an interaction term of remittances and private sector credit in equation 5 (REM*PSC). The results indicate that the interaction term REM*PSC coefficient is significant and positive. The interaction term REM*PSC suggesting that increasing domestic financial depth can provide the right investment vehicles through which remittances can be channeled and have a positive influence on economic growth.

Consistent with other studies, Openness is positive and significant except in equation (2) suggesting that open economies tends to grow faster (Catrinescu, et.al 2009, and Driffield and Jones 2013). Government consumption expenditure (GCON) parameter has a positive and significant coefficient except in equation (3) suggesting a positive contribution of fiscal policy to economic growth. This implies that fiscal discipline matters for economic growth. The parameter for inflation (INF) is negative and significant across the five equations, supporting the argument that inflation erodes purchasing power, affects consumption, lead to loss of value of fixed assets and leads to macroeconomic instability, ultimately resulting in a decline in economic growth.

The REER coefficient is significant and negatively affects real GDP per capita growth suggesting that even though most of COMESA member countries rely on imported capital goods, the impact of an appreciation on exports is negative translating into an adverse effect on economic growth. As expected, the coefficient on population growth (POP) is positive and significant across all the five equations. In addition, the coefficient of gross fixed capital formation (GFKF) is positive and significant across the five equations, implying that capital investment plays a positive and significant role in influencing economic growth (Kodama, 2012).

In Table 2, we conduct a robustness by estimating the same model but using Broad Money (BM) as a share of GDP, to capture financial sector depth instead of private sector credit as a share of GDP presented in Table 1. This helps to discern more clearly the role of domestic financial depth in determining economic growth. For our variables of interest, the results are consistent with Table 1 where only remittance variable is insignificant in the equation (8).

All the other macroeconomic fundamentals are consistent with the findings in Table 1 and with the expected signs. Consistent with the results in Table 1, the variable to capture financial depth - Broad Money has a significant and positive coefficient across equation (6) to equation (10), indicating that improved liquidity (as a measure 
of domestic financial depth) leads to increased access to credit by the private sector that in turn leads to increased investment and improvement in economic growth. This imply that the depth of the financial sector matters for economic growth. However, contrary to using private sector credit, the magnitudes of coefficients are relatively small. A one percent increase in broad money increases GPD per capita growth by between 0.0006 percent to 0.0008 percent in Table 2, compared with between 0.23 percent to 0.28 percent increase when using private sector credit (PSC) in Table 1. In both Tables (Table 1 and Table 2), domestic financial depth is an important determinant of economic growth in the COMESA region.

Table 2: Dependent Variable: GDP per capita growth (annual \%) - GDPKG

\begin{tabular}{|c|c|c|c|c|c|}
\hline System GMM Estimation & (6) & (7) & (8) & (9) & (10) \\
\hline $\begin{array}{l}\text { Lag GDP per capita growth } \\
\text { (annual \%)-GDPKG(-1) }\end{array}$ & $\begin{array}{l}0.267 * * * \\
(0.038)\end{array}$ & $\begin{array}{c}0.278 * * * \\
(0.039)\end{array}$ & $\begin{array}{c}0.278 * * * \\
(0.025)\end{array}$ & $\begin{array}{l}0.286^{* *} \\
(0.139) \\
\end{array}$ & $\begin{array}{r}0.268^{* * *} \\
(0.0423) \\
\end{array}$ \\
\hline $\begin{array}{c}\text { Foreign direct investment, net } \\
\text { inflows } \\
\text { (\% of GDP)-FDI }\end{array}$ & $\begin{array}{l}0.786^{* * *} \\
(0.156)\end{array}$ & & & & \\
\hline $\begin{array}{c}\text { Net ODA received } \\
\text { of GDP)-ODA }\end{array}$ & & $\begin{array}{c}0.710^{* * *} \\
(0.107)\end{array}$ & & & \\
\hline $\begin{array}{c}\text { Personal remittances, received } \\
\text { (\% of GDP)-REM }\end{array}$ & & & $\begin{array}{c}0.011 \\
(0.013)\end{array}$ & & \\
\hline $\begin{array}{c}\text { Total inflows as a percentage } \\
\text { of } \\
\text { GDP-Tinflows }\end{array}$ & & & & $\begin{array}{l}0.659^{* * *} \\
(0.019)\end{array}$ & \\
\hline REM*BM & & & & & $\begin{array}{c}0.694 * * * \\
(0.044)\end{array}$ \\
\hline $\begin{array}{c}\text { Broad money } \\
\text { (\% of GDP)-BM }\end{array}$ & $\begin{array}{c}0.0007 * * * \\
(0.0004)\end{array}$ & $\begin{array}{c}0.0007 * * * \\
0.0004)\end{array}$ & $\begin{array}{c}0.0008^{* * *} \\
(0.0003)\end{array}$ & $\begin{array}{c}0.0006^{* * * *} \\
(0.0001)\end{array}$ & $\begin{array}{c}0.0008^{* * * *} \\
(0.0002)\end{array}$ \\
\hline $\begin{array}{l}\text { Population Growth (annual \% } \\
\text { change)-POP }\end{array}$ & $\begin{array}{c}0.347 * * * \\
(0.089)\end{array}$ & $\begin{array}{c}0.363 * * * \\
(0.087)\end{array}$ & $\begin{array}{c}0.345^{* * * *} \\
(0.089)\end{array}$ & $\begin{array}{c}0.32 * * * \\
(0.086)\end{array}$ & $\begin{array}{c}0.297 * * * \\
(0.032)\end{array}$ \\
\hline $\begin{array}{c}\text { Gross Fixed Capital Formation } \\
\text { ( } \% \text { of GDP)-GFKF }\end{array}$ & $\begin{array}{l}0.26^{* * * *} \\
(0.043)\end{array}$ & $\begin{array}{c}0.281^{* * * *} \\
(0.074)\end{array}$ & $\begin{array}{l}0.29 * * * \\
(0.021)\end{array}$ & $\begin{array}{c}0.281 * * * \\
(0.021)\end{array}$ & $\begin{array}{l}0.138^{*} \\
(0.273)\end{array}$ \\
\hline $\begin{array}{l}\text { Inflation, GDP deflator (annual } \\
\% \text { )-INF }\end{array}$ & $\begin{array}{c}-0.003 * * \\
(0.002)\end{array}$ & $\begin{array}{c}-0.002 * * \\
(0.001)\end{array}$ & $\begin{array}{l}-0.003 * * \\
0.001)\end{array}$ & $\begin{array}{c}-0.003 * * \\
(0.001)\end{array}$ & $\begin{array}{c}-0.007 * * * \\
(0.001)\end{array}$ \\
\hline $\begin{array}{l}\text { General government final } \\
\text { consumption expenditure (\% } \\
\text { of GDP)-GCON }\end{array}$ & $\begin{array}{c}0.002 \\
(0.001)\end{array}$ & $\begin{array}{l}0.081 * * \\
(0.032)\end{array}$ & $\begin{array}{c}0.022 \\
(0.024)\end{array}$ & $\begin{array}{l}0.722 * * * \\
(0.089)\end{array}$ & $\begin{array}{c}0.646^{* * *} \\
(0.014)\end{array}$ \\
\hline Open (\% of GDP)-OPEN & $\begin{array}{c}0.679 * * * \\
(0.020)\end{array}$ & $\begin{array}{c}0.284 * * * \\
(0.021)\end{array}$ & $\begin{array}{l}0.720^{* * *} \\
(0.073)\end{array}$ & $\begin{array}{l}0.627 * * * \\
(0.033)\end{array}$ & $\begin{array}{c}0.694 * * * \\
(0.040)\end{array}$ \\
\hline REER & $\begin{array}{c}-0.085^{* * * *} \\
(0.029)\end{array}$ & $\begin{array}{c}-0.068 * * \\
(0.027)\end{array}$ & $\begin{array}{c}-0.097 * * * \\
(0.031)\end{array}$ & $\begin{array}{c}-0.087 * * * \\
(0.026)\end{array}$ & $\begin{array}{c}-0.088 * * * \\
(0.026)\end{array}$ \\
\hline
\end{tabular}




\subsection{Estimation of the REER Model}

Table (3) shows the system GMM results of the real effective exchange rate (REER) model. Equations (1), (2), (3) and equation (4) uses Foreign Direct Investments (FDI), Official Development Assistance (ODA), Remittances (REM) and total inflows (Tinflows) as a percentage of GDP for our four variables of interest respectively. Three of the capital inflows variables are significant and appreciates the REER. Specifically, a 1 percent increase in FDI, net ODA and total inflows leads to a 6.4 percent, 6.7 percent and 7.6 percent appreciation of the REER. However, remittance inflows parameter is not statistically significant, suggesting that remittances inflow to the region are mostly for consumption smoothing with little impact on economic growth. Remittances seems to be more countercyclical, helping households smooth their consumption during difficult times. The FDI, ODA and by accumulation total inflows seems to increase the productive capacity of the economies in the region and the resultant resource reallocation leads to REER appreciation. This suggests that FDI inflows are a more stable source of inflow and increases productive capacity of the economy through transfer of technology and know-how and with time leads more efficient resource allocation and an appreciation of the REER. Similarly, ODA inflows for some countries in the region have become almost a permanent feature and predictable, providing finance for development in the region.

In terms of the other macroeconomic fundamentals, the lagged REER variable has significant and positive coefficients across all the four equations suggesting that if the exchange rate was appreciating in the previous period, it will also appreciate in the current period and vice versa. A one percent appreciation of the REER in the previous period leads to about 0.63 percent appreciation in the current period across the four equations. Openness (OPEN) negatively affects REER, since trade restrictions affect the price of non-tradable goods. Increasing restrictions on tradable goods has a negative effect on the price of the tradable goods through the income effect and a positive effect through the substitution effect, so the income effect is less likely to dominate (Edwards, 1998). Trade restrictions hence push down the prices of tradable goods relative to non-tradable goods, leading to an appreciation of the REER. Conversely, trade openness pushes up the prices of tradable goods relative to non-tradable goods leading to a depreciation of the REER and hence the negative relationship. The coefficient on government consumption expenditure (GCON) is positive and significant, meaning that government spending leads to an appreciation of the REER since public spending is channeled towards non-tradable goods, increasing their prices relative to tradable goods. The coefficient of the Terms of Trade (TOT) variable significantly and positively affect REER since improvement in TOT causes the REER to appreciate to the extent that it improves the trade balance. 
Table 3: Dependent Variable: Real effective exchange rate (CPI-based) Index - REER

\begin{tabular}{|c|c|c|c|c|}
\hline System GMM Estimation & (1) & $(2)$ & (3) & (4) \\
\hline $\begin{array}{c}\text { Lag Real effective exchange rate (CPI-based) } \\
\text { Index-REER }(-1)\end{array}$ & $\begin{array}{c}0.632 * * * \\
(0.022)\end{array}$ & $\begin{array}{c}0.634 * * * \\
(0.021) \\
\end{array}$ & $\begin{array}{c}0.637 * * * \\
(0.015) \\
\end{array}$ & $\begin{array}{c}0.627 * * * \\
(0.046)\end{array}$ \\
\hline $\begin{array}{c}\text { Foreign direct investment, } \\
\text { net inflows ( } \% \text { of GDP)-FDI }\end{array}$ & $\begin{array}{c}0.635 * * * \\
(0.028)\end{array}$ & & & \\
\hline $\begin{array}{l}\text { Net ODA received } \\
(\% \text { of GDP })-O D A\end{array}$ & & $\begin{array}{c}0.666^{* * * *} \\
(0.041)\end{array}$ & & \\
\hline $\begin{array}{l}\text { Personal remittances, received } \\
\text { (\% of GDP)-REM }\end{array}$ & & & $\begin{array}{c}0.084 \\
(0.067)\end{array}$ & \\
\hline Total inflows as a percentage of GDP-Tinflows & & & & $\begin{array}{c}0.763 * * * \\
(0.097)\end{array}$ \\
\hline $\begin{array}{c}\text { Open is the sum of exports and imports of goods } \\
\text { and services ( } \% \text { of GDP)-OPEN }\end{array}$ & $\begin{array}{c}-0.359 * * * \\
(0.092)\end{array}$ & $\begin{array}{c}-0.344 * * * \\
(0.091)\end{array}$ & $\begin{array}{c}-0.340 * * * \\
(0.090)\end{array}$ & $\begin{array}{c}-0.341 * * * \\
(0.089)\end{array}$ \\
\hline Terms of Trade Index-TOT & $\begin{array}{c}0.622 * * * \\
(0.033)\end{array}$ & $\begin{array}{l}0.626 * * * \\
(0.045)\end{array}$ & $\begin{array}{c}0.636^{* * *} \\
(0.029)\end{array}$ & $\begin{array}{c}0.628 * * * \\
(0.026)\end{array}$ \\
\hline Balassa Samuelson Index-BSI & $\begin{array}{c}0.173 * * * \\
(0.046)\end{array}$ & $\begin{array}{c}0.26 * * * \\
(0.038)\end{array}$ & $\begin{array}{c}0.181 \\
(0.204)\end{array}$ & $\begin{array}{l}0.173 * \\
(0.101)\end{array}$ \\
\hline $\begin{array}{l}\text { General government final consumption expenditure } \\
\text { (\% of GDP)-GCON }\end{array}$ & $\begin{array}{c}0.422 * * * \\
(0.102)\end{array}$ & $\begin{array}{c}0.536 * * * \\
(0.107)\end{array}$ & $\begin{array}{c}0.126 * * * \\
(0.039)\end{array}$ & $\begin{array}{c}0.220 * * * \\
(0.068)\end{array}$ \\
\hline
\end{tabular}

BSI is used to capture the impact of the increasing price of non-tradable goods over the development process within a sample for which per capital GDP levels are quite heterogeneous. The BSI claims that productivity grows faster in the tradable than non-tradable sectors. Consequently, wages grow faster in tradable sector which spillover to the non-tradable sectors. The upward pressure on wages in the nontradable sectors is not matched by similar wage increases in the tradable sectors since prices in the tradable sectors are internationally determined and hence homogeneous across countries. Higher wages in the non-tradable sectors results in higher relative prices for non-tradable goods. This implies an increase in domestic inflation and an appreciation of the REER. The results indicate that the coefficient of the Balasa-Samuelson Index (BSI) is significant in the equation (1), equation (2) and equation (4) and not significant in equation (3) but with a positive sign. This suggest that FDI, Net ODA and total inflows have a more lasting influence on REER (tends to appreciate) possibly indicating that they tend to be more stable unlike remittances flows in these economies. 


\section{Conclusion and Policy Implications}

The study examines the link between capital inflows and economic growth for the economies of the Common Market for Eastern and Southern Africa (COMESA). With the region working towards establishing a monetary union, the role of capital inflows, a de facto measure of financial integration, will be a critical ingredient to this process (Mougani, 2012). The study finds a strong positive, significant and robust correlation of capital inflows with GDP per capita growth, support the positive role capital inflows play in bridging the saving and investment gap and providing financing for investment needs. However, capital inflows also leads to appreciation of the REER that may be detrimental to growth for the economies of the COMESA region.

In particular,

(a) The results from empirical estimation of the growth model shows that:

(i) FDI inflows, ODA inflows and Total inflows positively impacts economic growth for countries in the COMESA region. The coefficients of FDI, ODA and Total Inflows are positive and statistically significant, suggesting that FDI and ODA are important for economic growth and by extension the total inflows. ODA for some COMESA member countries contributes to human capital and infrastructure development, and provision of public goods such as public health, setting a country on the path of long-term economic growth. The FDI parameter is positive and a significant determinant of economic growth for countries in COMESA region. Consistent with other studies, this reinforces the FDI's role as stable and more reliable source of foreign finance and hence the need to promote policies that attract FDI (Haddad and Harrison, 1993). Notably, debt financing is more prone to adverse international development that forces developing countries to shoulder the negative effects of such developments by either paying higher premiums as markets rightly factor in more risk or defaulting on such commitments that tend to have devastating long term effects on the debtor country including full brown financial crisis and default. On the contrary, FDI financing builds shock absorbers and does not typically produce a sudden rush for exist but are committed for the long term. FDI can absorb and tolerate a certain amount of near-term adversity. Policy should endeavor to attract more FDI that can have stronger structural influences through horizontal and vertical linkages with the domestic economy. This would promote raw material processing and a larger participation in the global value chain, thereby creating employment and economic growth. Dependency on overseas development assistance need to be checked even though it continues to be an important source of development finance for the region's economy, in order to avoid donor fatigue. 
(ii) Remittances do not significantly influence economic growth possibly because remittances are used for consumption smoothing. This imply that there is room for remittances to play a critical role in influencing economic growth if appropriate investment vehicles are developed. The results of a positive and significant interaction term of remittances and a proxy for domestic financial depth further support this argument. Remittance contribute positive to GDP growth only when we interact it with a variable for domestic financial sector development, suggesting that going forward and as the region financial sector evolves, remittances will play more crucial role in determining economic performances of the countries in the COMESA region. This means that countries in the region need to continue implementing domestic financial sector reforms that will lead to a deeper financial sector, capable of harnessing and providing efficient vehicles that can direct remittances to investment, for remittances to have a significant contribution to economic growth in the region.

(iii) Most of the other fundamental determinants of growth have coefficients that are statistically significant and with the expected signs. Private sector credit, openness and fiscal discipline have positive and significant effects on real GDP per capita growth. With credit markets not so well developed, this imply that improving credit availability and access to the private sector, reducing trade restriction and encouraging more open trade regimes, and ensuring fiscal discipline, are important for increasing economic growth. In addition, development of domestic financial markets will encourage foreign participation, increase capital inflows while at the same time supporting access to credit by the private sector. These measures will improve domestic investment and spur economic growth in the regional economies.

(b) Examining whether capital inflows adversely affect economic growth, the study finds that except for the remittances whose effect is not significant, capital inflows leads to an appreciation of the REER across COMESA member countries. Specifically, FDI, ODA and total inflows leads to appreciation of the REER, that is statistically different from zero. This suggest that countries in the region should focus on attracting FDI inflows that provide a more stable source of capital inflows. The flexible exchange rates in most economies in the region allows the exchange rate to be an automatic stabilizer, and helps dampen real appreciation emanating from capital inflows. The results are consistent across the three capital inflows categories. In this regards, while implementing policies to attract capital inflows critical to finance development needs and spur economic growth, policy makers in the region should remain vigilant and ensure that there is no significant REER appreciation and loss of competitiveness that can lead to destabilizing macroeconomic management. The appreciation could impede growth but if capital inflows are directed to viable investments, can contribute to economic growth. The insignificance of the effect of remittances 
on REER may point to the counter-cyclical nature of remittances, mostly used to smoothen households' consumptions during macroeconomic shocks thereby not leading to changes in relative prices of tradable and non-tradable goods. FDI inflows and flexible exchange rate regime could assist in stemming the effect of appreciation and avoiding significant loss of competitiveness. Reducing dependency on foreign aid will continue to be an important policy prescription for some of the economies in the region especially those that heavily depend on ODA.

\section{References}

[1] Adedokun, A. J. (2017). Foreign aid, governance and economic growth in SubSaharan Africa: Does one cap fit all? African Development Review, 29, (2), 184-196.

[2] Alesiena, A, and Dollar, D. (2000). Who gives aid to whom and why? Journal of Economic Growth, 5.

[3] Aizenman, J., Jinjarak, Y. and Park, D. (2011). Capital Flows and Economic Growth in the Era of Financial Integration and Crisis, 1990-2010. NBER Working Paper, 17502, National Bureau of Economics, Cambridge, MA.

[4] Alley, I. (2015). Private Capital Flows and Economic Growth of Sub-Saharan African Countries. African Development Review, 27, (4), 469-83.

[5] Almfraji, M. A., Almsafir, M. K., and Yao, L. (2014). Economic growth and foreign direct investment inflows: the case of Qatar. Procedia-Social and Behavioral Sciences, 109, 1040-1045.

[6] Arellano, M., and Bond, S. (1991). Some tests of specification for panel data: Monte Carlo evidence and an application to employment equations. Review of Economic Studies, 58, 277-97.

[7] Arellano, M., and Bover, O. (1995). Another look at the instrumental variables estimation of error components models. Journal of Econometrics, 68, 29-51.

[8] Athukorala, P. C., Rajapatirana, S., (2003). Capital Inflows and the Real Exchange Rate: Comparative Study of Asia and Latin America. World Economy, 26, (4), 613-637.

[9] Blanchard, O. and Fischer, S. (1989). Lectures on Macroeconomics. The MIT Press, Cambridge.

[10] Blundell, R., and Bond, S. (1998). Initial conditions and moment restrictions in dynamic panel data models. Journal of Econometrics, 87, 11-143.

[11] Bourdet, Y. and Falck, H., (2006). Emigrants' Remittances and Dutch Disease in Cape Verde. International Economic Journal, 20, (3), 267-284.

[12] Burnside, C. and Dollar, D. (2000). Aid, Policies and Growth. American Economic Review, 90, 847-868.

[13] Calderon, C., and Nguyen, H. M. (2015). Do Capital Inflows Boost Growth in Developing Countries? Evidence from Sub-Saharan Africa. Policy Research Working Paper, 7298, World Bank, Washington, DC. 
[14] Calvo, G., Leiderman, L., and Reinhart, C., (1993). Capital Inflows and Real Exchange Rate Appreciation in Latin America: The Role of External Factors. IMF Staff Papers, 40, (1), 108-51.

[15] Catrinescu, N., Leon-Ledesma, M., Piracha, M. and Quillin, B. (2009). Remittances, institutions, and economic growth. World Development, 37, (1), 81-92.

[16] Cerra, V., Tekin, S., Turnovsky, S. J. (2008). Foreign Aid and Real Exchange Rate Adjustments in a Financially Constrained Dependent Economy. IMF Working Paper, 204, Washington: International Monetary Fund.

[17] Chami, R., Barajas, A., Cosimano, T., Fullenkamp, C., Gapen, M. and Montiel, P., (2008). Macroeconomic Consequences of Remittances. IMF Occasional Paper, 259 (Washington: International Monetary Fund).

[18] Cho, Y., and Tien, B. N. (2014). Sub-Saharan Africa's Recent Growth Spurt: An Analysis of the Sources of Growth. Policy Research Working Paper, 6862, World Bank, Washington, DC

[19] Collier, P. and Dollar, D. (2002). Aid Allocation and Poverty Reduction. European Economic Review, 46, 1475-1500

[20] Coon M. and Neumann R. (2015). Follow the money: Remittance responses to FDI inflows, MPRA Paper, 62220.

[21] Deléchat, C., Ramirez, G., Wagh, S. and Wakeman-Linn, J. (2009). Sub-Saharan Africa's Integration in the Global Financial Markets. IMF Working Paper No. 09, 114, International Monetary Fund, Washington, DC.

[22] De Mello, Jr., L. R. (1999). Foreign Direct Investment-Led Growth: Evidence from Time Series and Panel Data. Oxford Economic Papers 51, (1), 133-51.

[23] Driffield, N and Jones, C. (2013). Impact of FDI, ODA and migrant remittances on economic growth in developing countries: a systems approach. The European Journal of Development Research, 25, (2), 173-196.

[24] Easterly, W., Levine, R. and Roodman, D. (2004). Aid, policies, and growth: Comment. American Economic Review 94, (3), 774-780.

[25] Edwards, S. (1998). Capital Flows, Real Exchange Rates, and Capital Controls: Some Latin American Experiences. NBER Working Papers, 6800 (Cambridge, MA: National Bureau of Economic Research, Inc.).

[26] Giuliano, P. and Ruiz-Arranz, M. (2009). Remittances, Financial Development and Growth. Journal of Development Economics, 90, 144-152.

[27] Gourinchas, P. O., and Jeanne. O. (2013). Capital Flows to Developing Countries: The Allocation Puzzle. Review of Economic Studies 80, 1484-515.

[28] Haddad, M., and Harrison, A. (1993). Are there positive spillovers from direct foreign investment? Evidence from panel data for Morocco. Journal of Development Economics, 42, (1), 51-74.

[29] Javaid, W. (2017). Impact of remittances on consumption and investment: Case study of Tehsil Sargodha, Punjab, Pakistan. Journal of Finance and Economics, 5, (4), 156- 163.

[30] Kinda, T. (2009). Investment Climate and FDI: Firm-level Evidence. World Development, 38 (3), 498-513. 
[31] Kodama, M. (2012). Aid unpredictability and economic growth. World Development 40, (2), 266- 272.

[32] Kose, M. A., Prasad, E., Rogoff, K. and Wei, S. J. (2010). Financial Globalization and Economic Policies. In Handbook of Development Economics Vol. 5, edited by D. Rodrik, and M. Rosenzweig, 4283-359. Amsterdam: North-Holland.

[33] Lartey, E. (2007). Capital Inflows and the Real Exchange Rate: An Empirical Study of Sub-Saharan Africa. Journal of International Trade \& Economic Development, 16 (3), 337-57.

[34] Lartey, E. (2008). Capital Inflows, Dutch Disease Effects and Monetary Policy in a Small Open Economy. Review of International Economics, 16, (5), 971989.

[35] Lensink, R. and Morrissey, O. (2000). Aid instability as a measure of uncertainty and the positive impact of aid on growth. Journal of Development Studies, 36, (3), 31-49.

[36] Lensink R. and White, H. (2000). Aid allocation, poverty reduction and the Assessing Aid Report. Journal of International Development, 12.

[37] MacDonald, M. (2015). Patterns of International Capital Flows and Productivity Growth: New Evidence. Review of International Economics, 23, (5), 846-72.

[38] Mckinnon, R. and Pill, H. (1997). Credible Economic Liberalizations and Over borrowing. American Economic Review, 87, (2).

[39] Minasyan, A. and Nunnenkamp, P. (2016). Remittances and the effectiveness of foreign aid. Review of Development Economics, 20, (3), 681-701.

[40] Mougani, G. (2012). An Analysis of the Impact of Financial Integration on Economic Activity and Macroeconomic Volatility in Africa within the Financial Globalization Context. Working Paper, 144, February, African Development Bank, Tunis.

[41] Murinde, V. (2012). Financial Development and Economic Growth: Global and African Evidence. Journal of African Economies, Oxford University Press, 21, (1).

[42] Obstfeld, M. (1994), Risk-Taking, Global Diversification, and Growth. American Economic Review, 84, (5).

[43] Omri, A. and Kahouli, B. (2014). The Nexus among Foreign Investment, Domestic Capital and Economic Growth: Empirical Evidence from the MENA Region. Research in Economics, 68, (3), 257-63.

[44] Pradhan, M., Balakrishnan, R., Baqir, R., Heenan, G., Nowak, S., Oner, C. and Panth, S. (2011). Policy Responses to Capital Flows in Emerging Markets. IMF Staff Discussion Note, SDN/11/10, April 21, Asia and Pacific Department, International Monetary Fund.

[45] Rajan, R. and Subramanian, A. (2005). What Undermines Aid's Impact on Growth? NBER Working Paper, 11657 (Cambridge, MA: National Bureau of Economic Research). 
[46] Rodrik, D. and Velasco, A. (1999). Short-term Capital Flows. NBER Working Paper, 7364.

[47] Saadi-Sedik, T. and Petri, M. (2006). To Smooth or Not to Smooth - The Impact of Grants and Remittances on the Equilibrium Real Exchange Rate in Jordan. IMF Working Paper, WP/06/257, Washington: International Monetary Fund.

[48] Saborowski, C. (2009). Capital Inflows and the Real Exchange Rate: Can Financial Development Cure the Dutch Disease? IMF Working Paper, 09/20 (Washington: International Monetary Fund).

[49] Solow, R. (1956). A contribution to the theory of economic growth. The Quarterly Journal of Economics, 70, (1), 65-94.

[50] Quattara, B. (2006). Foreign aid and government fiscal behavior in developing countries: Panel data evidence. Economic Modeling, 23, 506-514.

[51] World Bank. (1998). Assessing Aid. What Works, What Doesn't and Why. Oxford University Press, New York.

[52] Zardoub, A. and El Abed Riadh. (2019). Short and Long-Term Effects of Financial Flows on Economic Growth. Journal of Economic Integration, 34, (4), 705-724.

\section{Appendix}

\section{List of COMESA Member Countries}

1. Countries with data included in the study

Burundi (BRD), Comoros (COM), Democratic Republic of Congo (DRC), Egypt (EGY), Eswatini (ESW), Ethiopia (ETH), Kenya (KEN), Madagascar (MAD), Malawi (MAL), Mauritius (MAU), Rwanda (RWA), Seychelles (SEY), Sudan (SUD), Tunisia (TUN), Uganda (UGA), Zambia (ZAM), and Zimbabwe (ZIM).

2. Countries that have data gaps and could therefore not be included in the study are: Djibouti (DJ), Eritrea (ER), Libya (LY) and Somalia (SO). 
Table 1A: List, Definitions, and Sources of Variables

\begin{tabular}{|c|c|c|}
\hline Variable & Definition & Source \\
\hline GDPKG & GDP per capita growth (annual \%) & $\begin{array}{l}\text { World Development Indicators (WDI) and } \\
\text { World Economic Outlook (WEO) data }\end{array}$ \\
\hline FDI & $\begin{array}{l}\text { Foreign direct investment, net } \\
\text { inflows ( } \% \text { of GDP) }\end{array}$ & UNCTAD data base \\
\hline ODA & Net ODA received (\% of GNI) & $\begin{array}{l}\text { World Development Indicators (WDI) and } \\
\text { World Economic Outlook (WEO) data }\end{array}$ \\
\hline REM & $\begin{array}{l}\text { Personal remittances, received } \\
\text { (\% of GDP) }\end{array}$ & UNCTAD data base \\
\hline REER & $\begin{array}{l}\text { Real effective exchange rate } \\
\text { (CPI-based) }\end{array}$ & $\begin{array}{c}\text { International Financial Statistics (IFS) and } \\
\text { calculations from } \\
\text { http://www.bruegel.org/publications/publication- } \\
\text { detail/publication/716-real-effective-exchange- } \\
\text { rates-for-178-countries-a-new-database/ }\end{array}$ \\
\hline OPEN & $\begin{array}{l}\text { Trade is the sum of exports and } \\
\text { imports of goods and services } \\
\text { measured as a share of gross } \\
\text { domestic product. }\end{array}$ & $\begin{array}{l}\text { World Development Indicators (WDI) and } \\
\text { World Economic Outlook (WEO) data }\end{array}$ \\
\hline INF & Inflation, GDP deflator (annual \%) & $\begin{array}{l}\text { World Development Indicators (WDI) and } \\
\text { World Economic Outlook (WEO) data }\end{array}$ \\
\hline GFKF & $\begin{array}{l}\text { Gross Fixed Capital Formation } \\
(\% \text { of GDP) }\end{array}$ & $\begin{array}{l}\text { World Development Indicators (WDI) and } \\
\text { World Economic Outlook (WEO) data }\end{array}$ \\
\hline GCON & $\begin{array}{l}\text { General government final } \\
\text { consumption expenditure } \\
\text { (\% of GDP) }\end{array}$ & $\begin{array}{l}\text { World Development Indicators (WDI) and } \\
\text { World Economic Outlook (WEO) data }\end{array}$ \\
\hline BM & Broad money ( $\%$ of GDP) & $\begin{array}{l}\text { World Development Indicators (WDI) and } \\
\text { World Economic Outlook (WEO) data }\end{array}$ \\
\hline GCON & $\begin{array}{l}\text { Government final consumption } \\
\text { expenditure as a percent of GDP }\end{array}$ & World Bank - World Development Indicators \\
\hline TInflows & Total inflows & $\begin{array}{c}\text { Authors calculation from UNCTAD data base- } \\
\text { Calculated as the sum of FDI, ODA and REM as } \\
\text { a percentage of GDP }\end{array}$ \\
\hline BSI & $\begin{array}{l}\text { Balassa Samuelson Index is } \\
\text { computed as a country's GDP per } \\
\text { capita relative to the weighted } \\
\text { average GDP per capita of } \\
\text { COMESA's five major trading } \\
\text { partners (namely European Union, } \\
\text { United Arab Emirates, South Africa, } \\
\text { China and COMESA countries) }\end{array}$ & $\begin{array}{l}\text { Author's calculation - Calculated as the average } \\
\text { of the } 5 \text { major trading partners average GDP per } \\
\text { capita divided by SSA average GDP per capita. } \\
\text { The resulting weighted index is used to divide } \\
\text { each country GDP per capita. }\end{array}$ \\
\hline PSC & $\begin{array}{c}\text { Domestic credit to private sector (\% } \\
\text { of GDP) }\end{array}$ & International Financial Statistics - IMF \\
\hline POP & Population growth (annual \%) & World Bank-World Development Indicators \\
\hline TOT & Terms of Trade Index & UNCTAD data base \\
\hline
\end{tabular}

